\title{
THE ROLE OF IRONY AND BACKGROUND KNOWLEDGE IN CONTEXT DECODING OF THE ESSAY "EXCAVATING RACHEL'S ROOM" BY R. J. WALLER
}

\section{Diadechko A.}

$\mathrm{PhD}$ in Philology, Associate Professor

Sumy State University

R.-Korsakov St., 2, Sumy, 40007, Ukraine

ORCID ID 0000-0002-4505-5094

dyadechko@hotmail.com

The article deals with the phenomenon of irony, so typical for modern literary pieces and interpersonal communication in general. It is focused on the tools used for constructing, realizing, and decoding of irony in modern American non-fiction prose, namely in the essay, written by Robert James Waller. Extra-linguistic nature of irony and its contextual predetermination are stated. Two types of irony are distinguished: situational and associative. Associative irony which deals with mega-contexts is specified. Its context decoding with reference to basic categories and principles of contextual semantics, coherence, cohesion, retrospection, intertextuality among them, is practiced and described. Its multi-levelled complicated structure is outlined and detailed through a logical, stylistic, and component analysis of the text, and detection of implicitly presented meanings and senses. Typical examples of contextual decoding of irony are also given. The cases of using repetition, citation, and parody are exemplified.

The role of background knowledge in reconstructing true senses initially meant by the author of the essay is investigated. Particular specific and additional information needed by non-native readers to understand the intentions, considerations, and emotions of R.J.Waller, and to decode ironical senses built by him, is defined and supplemented. Temporal features of background knowledge are noted.

Keywords: irony, situational irony, associative irony, context decoding, subjective and evaluative modality, background knowledge.

Introduction. Asymmetric nature of language in general, and textual units in particular, cause the necessity to find tools for striking a logical balance between the form and the content in the language system for adequate communication. Only context appears to be the right tool which can offer a proper sense due to communicative situation. Irony features the same asymmetry. It primarily consists in contradiction, contrast between the content and its presentation.

People produce irony willingly and disclose it eagerly. For centuries they have been playing this both linguistic and cognitive game. Being first intentionally produced and further understood through its decoding, irony provides them with communicative comfort and pleasure. Motivated by extra-linguistic situation and brought about by context, irony cannot be decoded beyond it.

Within the last five decades, the concept of irony has been increasingly developed and actively discussed by both foreign and home literature expects and linguists. Initially approached as a pure instrument, a trope, a lexical and stylistic tool, irony has acquired a new additional vision in terms of pragmatics when considered by means of contextual semantics with its basic categories and methods. This combined approach allowed to view irony as a device as well as a result it produces if applied [1, 2, 3, 4, 5]. It gradually gained a broader social sense coming within a new global trend towards skepticism, relativism, liberalism, and positivism so typical for modern literature, arts, philosophy, and presenting

(C) Дядечко А. М., 2019 
in this way a new critical view on reality and human values. Irony, ironical vision of human life, is one of the basic features of modern interpersonal communication. Modern scholars are united in their recognition of one more defining feature of irony. It is stated to transfer, though indirectly, in some undersurface way, the author's thinking, what is being regarded as a specific type of subjective and evaluative modality. What is more, this type of modality is considered to be the main communicative task of irony $[1,6]$.

It is worth noting that, while being a global trend, irony is most commonly applied in the English language literature as a part of its writing tradition. British and American writers have been cultivating an ability for self-criticism and an ironical view on the world around them $[3,7,8]$.

Although most of the works dealing with the studies of irony are devoted to fiction pieces analysis, an essay as a literary genre does not seem to be entirely different in its expressiveness, figurativeness, as well as in its subjective and evaluative modality realized by means of irony. The essays by Robert James Waller (1939-2017) can make a perfect example of producing ironical senses in non-fiction pieces [9].

Thus the purpose of the study is to analyze the ways by which the ironical senses of R. J. Waller's essay "Excavating Rachel's room" can be contextually decoded and to investigate to what extent background knowledge, being their significant and meaningful constituent, can be essential and decisive for understanding the author's visions and intentions by the readers, non-native readers in particular.

The object of the study is the essay "Excavating Rachel's room" by R. J. Waller.

The subject of the study is a set of tools employed by R. J. Waller to construct ironical senses as well as the amount and the role of background knowledge which a nonnative reader may additionally and specifically need for context decoding.

As for methods applied in the study, they integrate discourse analysis, context analysis, presupposition method, semantic and stylistic analysis, component analysis, and interpretation dictionary data.

In contrast to foreign typology of irony with its three options (verbal, situational, and dramatic types), most of domestic scholars follow the traditions and classification outlined by S. I. Pokhodnya in her profound and programming work on irony. Thus, they unify classification of irony by reducing it to two basic types, namely, situational, with its two subtypes referred to micro- and macro-contexts, and associative irony coming along with mega-contexts. These two types of irony require different conditions as well as means of their actualization. Situational irony is known to be commonly found in speech acts, it brings lexically and emotionally colored details. This type of irony is always obvious and realized in a linear context, typically within a sentence or a paragraph. Associative irony, in its turn, being a multifocal and multifunctional type of irony, is noted for its most complicated structure and hierarchy. This type of irony is commonly analyzed within entire stories $[3,7,8]$.

In this study, we consider the type of an essay which has become a part of the literary canon of modern American non-fiction literature, namely a magazine and newspaper essay. It is a short literary composition on a particular theme or subject, usually in prose and generally analytic, speculative, or interpretative. In the USA, this sort of essays has turned into a kind of literary media, for they are typically produced by best known social media icons called publicists or polemicists [10]. Their writings reveal their personal self-esteem and influence American society in a challenging and thought-provoking way. As practice of modern mass media shows, irony has become one of the most distinctive features of this kind of communication. Modern publicists purposely and intentionally convey ironical senses, mostly at mega-contest level, in order to supplement and emphasize their messages.

In the early 1980s, R. J. Waller began writing travel, nature, and personal essays for daily morning newspaper in Iowa. His book "Old Songs in a New Café", published first in 1994, collected some of his newspaper columns about marriage, fatherhood, and middle age. In the study, one essay from this book, namely "Excavating Rachel's Room", is 
specifically considered. The plot of the essay is simple if not trivial. Waller's only daughter Rachel left her family home for university studies in Boston, and her farther has to reconsider eighteen years of his fatherhood. The essay is set within a particular spatial and temporal context - the Midwestern USA of the early 1980s and eighteen years more in retrospect. When writing for the newspaper, Waller evidently addressed his narration to native readers, i.e., his potential recipients were expected to be set within common cultural, social, political, educational, linguistic, and many other kinds of surroundings. They were assumed to share a certain amount of background knowledge essential for understanding Waller's texts as well as senses imbedded in them. All these immensely contributed to the context. Presumably, a non-native reader of today may face serious difficulties as for Waller's context decoding due to the lack of corresponding background knowledge.

Once our study is based preferably on an essay (mega-context), associative irony realized and recognized at different communicative levels, its dependence on their structure and hierarchy is expected to be lit upon within the entire essay format. Associative irony comes along complicated contexts in which their meaningful constituents are placed both directly in a contact and distantly It appears to be both a lingual and a cognitive tool. The more implicit are the forms which associative ironical senses take, the higher value their contexts acquire and the more complicated mechanisms they need to be decoded. Associative irony analysis can only be possible if discussed in terms of the key categories and principles of the contextual semantics with its special focus on the vertical context and background knowledge, though to convey associative ironical senses authors may integrate both linear and vertical contexts. Their adequate decoding needs three types of presupposition. Textual type of presupposition provides adequate interpretation of the whole story. Extra-linguistic presupposition is based on the knowledge of geography, history, culture, national traditions, habits, mentality. Finally, intertextual presupposition deals with interpretation of linguistic, historical knowledge and require some educational background. That is why the last two types of presupposition are known to emphasize the role of background knowledge [3].

The basis of a general linguo-cognitive model of ironic utterance is defined as a dissonance between the true sense and the contextual background causing the break of logical referential links. Just reading the title of the Waller's essay alone causes us to imagine excavations, i.e., uncovering earth layers by digging. Although explanation comes almost immediately with the second passage in a linear context: "With her eighteenth birthday near, Rachel has moved to Boston, leaving her room and the cleaning of it to us" $[9$, p. 1]. The readers are staying within this extended metaphor as the story progresses, and Waller distantly but continuously uses such words such as "archeologists", "to move down through the layers", "salvage", "we reached the level" in further paragraphs. Excavation is contrasted to room cleaning, being an example of a lexical and syntactical level of associative irony.

Trivial things of everyday use, their imitated importance, though critically viewed, are deliberately presented by Waller in a highly elevated style. This both lexical and stylistic improperness results in humorous effect. Waller presents the doll Barbie as "sexist glorification of middle-class values" [9, p. 5]. He uses the word "glorification", which means "giving adoration and thanksgiving, worshipping, giving honor." He also uses the words "shrine" (a tomb containing holy relics), and "paean" (in American English it is a song of thanksgiving, praise or triumph) for the same effect when describing Rachel's room: "It stands as a shrine to questionable taste, a paean to the worst of American consumerism" [9, p. 3]. To express his first impression of the mess in his daughter's room, Waller uses the verb "to undulate" (to impress extremely through emotions). All the examples above exemplify the so called "blame by praise" technology based on negation. The word "salvage" (things saved from loss or disaster) said about hammer, six dollars in change, five sets of keys to the Toyota, things once lost and then found thanks to room cleaning, also brings stylistic dissonance. In contrast, such words as "my ravings" (foolish 
or wild talk) go in a deliberately low and negative style to indicate uselessness of father's talk.

Throughout the story, Waller, being both honest and ironical about things Rachel cannot do well, avoids blaming her while viewing the situation humorously, as she is a part of him. He just adores her. Being hopeless about his daughter's ability to understand algebra but unable to blame her, Waller humorously comments on the situation to make him and his daughter feel united: "She nodded, smiling, and laughed when I admitted that not once, in all my travels, had I ever calculated how long Smith would need to overtake Brown if Brown left three hours before Smith on a slower train. I told her I'd sit in the bar and wait for Smith's faster train. That confirmed what she had heretofore only expected algebra is not needed for the abundant life, only fast trains and good whiskey" [9, p.6].

Ironical senses are constructed by Waller to produce not only a humorous effect. They make a powerful tool to create images as they come to the author's mind and are generally viewed by him within his entire picture of reality. Regret, sorrow, pity, and irritation are conveyed in the paragraph about garbage truck and the men who operate it. They are enemies because they are going to destroy and make gone forever the reminders of Rachel's "years of childhood and beyond" [9, p. 6], their visual evidence, so dear to her dad. Deeply caring father and totally indifferent about the same things garbage guys are vividly contrasted. Metaphors come in succession to signify high expressiveness and emotional scale of the context. "...I walk to the road again and look at the pile. The tailings of one quarter of a life stacked up in three dozen bags. It seems like there ought to be more.

When I hear the garbage truck, I peer out of an upstairs window in her room. The garbage guys have seen lives strung out along road edges before and are not moved. The cruncher on the truck grinds hair curlers and Twister and junk jewelry and broken stuffed animals - and some small part of me" $[9, \mathrm{p} .6]$.

To describe his new life without his daughter around, Waller contrasts "before" and "now": "Her room has turned into a den. A computer replaced curling irons and other clutter on her desk. My pinstripes look cheerless in her closet where pink fish-net tops and leather pants once hung. Order has replaced life" [9, p.7]. Thus contrasted pairs, first material, then immaterial, "room-den", "computer-curling irons", "pinstripes-fish-net tops and leather pants", "order-life" go repeatedly to associate father's anxiety, loneliness, and missing his daughter.

To decode the context, associative ironical senses in particular, we have to rest our analysis on such basic textual categories and the ways of their realization as coherence, cohesion, retrospection, intertextuality (achieved through allusions, citations, parody) [3]. We can understand discourse because of its connectedness. While coherence must obtain the whole of the text, make its logical integrity, cohesion is provided by different types of repetitions and a variety of connectors. Repetition appears to be a cohesive device, which provides expressiveness and integrity in its own way. It gives emphasis or emotive heightening to the repeated meaning, calls readers' attention to a specific point, gives them a clue. It also contributes to the explicit content of the utterance. Lexical and stylistic repetition of linguistic units is one of the most potent and frequently used devices.

The examples of anaphora in Waller's text are multiple. In the one below, gradually extended syntactical structure brings into focus a number of objects as if making video recording of the scene: “And there's Barbie. And Barbie's clothes. And Barbie's camper in which the young female cat was given grand tours of the house..." [9, p. 5].

Cohesion through repetition is significantly enforced by simultaneous use of such textual category as retrospection. Throughout all his narration, Waller goes eighteen years in retrospect, as his memories bring him back to the time of his daughter's arrival, childhood, and her teenage years: “... we describe to each other the night of her birth, how she looked coming down the hall in the Bloomington, Indiana, hospital on the gurney in her mother's arms. How we felt, how we feel, what we did and didn't do" [9, p. 3]. 
The repetition of lexical units coupled with the repeated syntactical structures may remind the readers that the essay was produced by an experienced lyricist. Rhythm seems to come through Waller's lines:

"I hope she goes where's laughter and romance, and walks the streets of Bombay and leans out of Paris windows to touch falling January snow and swims in the seas off Bora Bora and makes love in Bangkok in the Montien Hotel.

I hope she plays blackjack all night in the Barbary Coast and,... watches the sun come up in Vegas. I hope she rides the big planes out of Africa and Jakarta and feels what it's like to turn to home just ahead of winter" [9, p. 8].

Typically, the effect of associative irony is increasingly growing towards the end of the story. This accumulative effect is also vivid in Waller's essay. To make the concluding paragraphs of the essay impressive and memorable, to make hidden evident, to explicit what was only meant before, Waller intentionally switches to elevated style bringing together all his love, adoration, hopes, wishes, and blessings addressed to his daughter. He repeatedly says his emphatic and even pathetic phrases as if in a coda in a piece of music:

"Go well, Rachel Elizabeth, my daughter. And, go knowing that your ball glove hangs on the wall beside mine, that Snoopy's pennant flies bravely in the old airs of your room, that the violin is safe, and the little cat now sleeps with us at night but still sits on the porch railing in the late afternoon and looks for you" $[9$, p. 8].

Numerous syntactical means applied by Waller for generating ironical senses also include parenthesis, rhetorical questions as well as one-member sentences. Several examples of parenthesis in mid- and end-positions, which interrupt sentences and serve as Waller's personal comments on what he says, can be found in the essay text. They extend the author's attitude towards some problem or idea and address readers directly. In Waller's text these words and phrases are marked off by dash or commas. Parents' embarrassed reaction to the view of Rachel's room is easily understood through the phrase "The room well - undulates" [3, p. 3]. The phrases "She has a deep caring for the animals and purposely, we know, avoids saying good-bye to them..." [9, p. 2] and "It is, I propose, some furry guardian of teenage values, and it senses, correctly, that we are enemies" $[9, \mathrm{p}$. 3] might serve as examples of using stereotyped conversation formulae. Both examples emotionally and humorously express Rachel's affection for pets, which she had to leave to her parents and which presence make them remember her. Imaginary or possible reaction of the grown up cat, once forced into Barbie's camper, is also marked with parenthetical reply presumably coming from the cat: “...Barbie's camper in which the young female cat was given grand tours of the house, even though she would have preferred not to travel at all, thank you" [9, p. 5]. To make the readers feel involved in card playing, Waller parenthetically uses an imperative so typical for card players in the following sentence: "I hope she plays blackjack all night in the Barbary Coast and, money ahead, watches the sun come up in Vegas" [9, p.8].

The quiet but anxious flow of Waller's thoughts and speculations about his adult daughter is marked with one-member sentences consisting of nouns: "A job" $[9, p .6]$ "Letters" [9, p. 7]. There are also examples of extended nominative sentences consisted of an attributed noun and placed in the same context: "Good stuff" $[9, \mathrm{p} .4]$, "Blank stare" [9, p. 6].

Rhetorical questions make another tool that R. J. Waller refers to when generating his ironical senses: "I have strange feelings, though. Have we sorted carefully enough? Probably" [9, p. 6]. Besides, Waller managers to combine rhetorical questions with unextended one-member nominative sentences:

"Regrets? A few. Victories? A few" [9, p.7].

If linguistic context refers to the study of semantic units of the language in reference to their linguistic environment, extra-linguistic context, commonly defined as "vertical context", can be decoded by competent recipients (readers) who are aware of things discussed and considered. A reader is expected to reconstruct in his mind what is not 
explicitly expressed, while a narrator expects a reader to have a proper level of intelligence and a proper amount of background knowledge. The background knowledge must be common for all the participants of communication. It is background knowledge that helps readers understand/decode ironical senses based on allusions, images, metaphors, citations, parodies.

Our analysis of ironic context decoding, i.e., investigation of how irony enforces author's theme, ideas, and emotions, is performed with the reference to both native and non-native reader's and explorer's cognition. Therefore, this study of Waller's ironical contexts is purposely accompanied with some supplemental information needed to balance indirect formal presentation and adequate understanding of the author's ideas and intentions. This referential information might serve as a hint, especially for non-native recipients, for their further interpretation of ironic senses. Let us focus on those parts of the essay where ironical senses decoding appears to be the most complicated because of their implicit references to other texts and resources.

A lot of proper names are mentioned in the essay to locate Waller's narration geographically. Native readers probably know that Cedar Falls where the Wallers live, can be found in Black Hawk County, which is in Iowa, a state in the Midwestern United States. Rachel flies to Boston from Waterloo Regional Airport, also known as Livingston Betsworth Field, a public use airport located 4 miles from northwest of the center of business district of Waterloo. The name of company is Air Wisconsin Airlines, which is a regional airline, based at Appleton International Airport in the town of Greenville, Wisconsin, United States: "We watch her walk across the apron of the Waterloo airport, clutching her ticket, and she disappears into the funny little Air Wisconsin plane" [9, p. 2]. The knowledge of the locations described above completes the description of the scene and adds much to Waller's as well as readers' emotions: "Turning, just as she left the departure lounge, she grinned and flashed the peace sign. I was all right until then, but with that last insouciant gesture, so typical of her, the poignancy of the moment is driven home and tears come" $[9$, p. 2].

Waller wants his dearest daughter to see and enjoy the most attractive and romantic parts of the world which he himself happened to visit. He prospectively sees Rachel in Bombay, Paris, Bangkok, Jakarta, Las Vegas, the seas of Bora Bora (French Polynesian resorts) and the Barbary Coast (a red-light district during the second half of the $19^{\text {th }}$ century and early $20^{\text {th }}$ century in San Francisco which featured dance halls, concert saloons, bars, jazz clubs, variety shows, and brothels, and which is presently known as a luxurious resort place with gambling facilities and marijuana shops). Admittedly, the information given above is really needed by both kinds of readers, native and non-native, to understand Waller's ironical senses.

Evidently, with Barbie and Ken dolls description, these two American symbols, Waller parodies an American society, its values, and way of life. Children toys are presented versus a typical American family couple, children values are shown versus adults' values. It is obvious that Waller's speculations on this point are produced for humorous effect, although the social issues touched by him briefly might become an object for more serious consideration if placed within another context: "My ravings about sexist glorification of middle-class values personified by Barbie seem stupid and hollow in retrospect... Ken is not in sight. Off working out on the Nautilus equipment, I suppose. Or studying tax shelters" $[9$, p. 5]. In contrast to native readers, Ukrainian readers need to be informed that "Nautilus Inc." is an American worldwide marketer, developer, and manufacturer of fitness equipment, and that tax shelters are methods of reducing taxable income to pay less to tax collecting entities. When Waller mentions Twister, which appeared in 1966 as a game of physical skill, he applies for citation as the game-producer promotes its product in the market the slogan Waller literally presents in the essay: "The Game That Ties You Up in Knots" [9, p. 5].

There is a paragraph in the essay which can provoke, though quite doubtfully, the case of paraphrased citation. It deals with Frank Sinatra's song popularized in the USA in 
1969. The lyrics of the song go like: "Regrets, I've had a few. But then again, too few to mention". As for Waller's piece, he starts the paragraph with very lexically similar oneword sentences "Regrets? A few....", though further he repeatedly uses extended sentences with anaphora, enlarging on his feelings and emotions: "I wish I had walked in the woods more with her. I wish I have gotten mad less and laughed longer" [9, p. 7]. There is no evidence for possible coincidence. Probably, we can only make an assumption that Waller, who wrote so many lyrics to his songs and sang them, could partly "borrow" a couple of lines from Sinatra's song. This song is about a man looking back on a life he has lived on his own terms. Whatever truth might be, the emotions worded in Sinatra's song seem to be very close to those experienced and depicted in Waller's piece. What is really evident is that a similar tool was used by both authors to produce the same sense of feeling regret.

To show that Rachel, with her father having a degree in Mathematics, was far from being good at algebra, Waller mentions the names of two American celebrities of the 1980s. While paraphrasing their citations about mathematics: "Night after night, for a year, I sat with her at the kitchen table, failing to convince her of the beauty to be found in quadratic equations and other abstractions. I goaded her with Waller's Conjecture: "Life is a word problem". Blank stare. Finally, trying to wave hope in the face of defeat, I paraphrased Fran Lebowitz: "In the real world there is no algebra" [9, p.6]. To understand and decode this context one has to know specifically that Willard W. Waller (1989-1945) was an intellectual and emotional social rebellion, sociologist, who wrote on the family, education and war issues. He also demonstrated familiarity with statistical methods. The second person, whose words Waller admits being paraphrased, is Fran Lebowitz (Fransis Ann Lebowitz, born in 1950) - an American author, public speaker, and occasional actor. She is known for her sardonic social commentary on American life. Her original collocation can be found in her book "Symbols and Meanings in School Mathematics" published in 1982. Surprisingly, Fran Lebowitz has been bitterly criticizing the Republican Party for many years and today, she is known for her critical attitude to President Donald Trump. Thus we may witness, how Waller, though unintentionally, bridged two centuries and how his context can be even enlarged by concerned readers.

At present the dog named Snoopy is already easily recognized by both young Ukrainian readers and their American peers, but not many of them seem to be in the know that it first appeared in 1950, in a comic strip, as Charlie Brown's pet beagle, and that with time it has become one of the most recognizable and iconic characters in the comic strip, and in other countries (probably, in Ukraine too) is considered to be more famous than his owner. In the essay, Snoopy is just briefly mentioned among other toys: "I rescue Snoopy's pennant from a flapping jaws of a trash bag..." [9, p. 5].

Once acknowledged with Waller's life and works, we understand that music is immensely important not only for Waller himself, a composer and musician. Naturally, he had let music come and stay in his daughter's life. We can read that Rachel's playing the violin in Jim Welch's school orchestra "was one of the best parts of her growing years" [9, p. 5 ]. But only a careful reader can understand the Waller's words adequately if he finds out that Jim Welch (James D.Welch, 1927-2002), worked as a teacher of orchestral music in several cities of the USA, Cedar Falls among them. He taught and played cello, and retired in 1987. To illustrate musical preferences of his teenage daughter, Waller mentions such names as "Def Leppard" - an English rock group, which was first formed in 1977, became popular in 1980-83, released their last album in 2018, and "Twisted Sister" - an American heavy metal band (1972-2016). Particularly, the knowledge of the fact that many of the songs of the second band explore themes of parents vs. child conflicts, criticism of the educational system, seems to be extremely essential for Waller's context decoding. Certainly, Ella Fitzgerald, the $1^{\text {st }}$ lady of jazz, (1917-1996), if not totally, but is yet recognizable by many native and non-native readers.

Personally, I have had about twenty years long experience of discussing Waller's essays in the class, "Excavating Rachel's room" among them, with my Ukrainian students, and I can witness how background knowledge evolves and undergoes transformation with 
time. Probably, it refers to Waller's native readers as well, especially the youngest of them. Due to globalization, modern technologies, marketing development, Ukrainian readers have become better aware of things related to leisure and entertainment products for children. More and more of them have played with Barbie, with her camper, Kent, and Twister. In the same way, their watching American movies results in their knowledge of such terms of baseball as "sport-baseball glove" and "base" they come across when reading Waller's essay: "She (Rachel) was pretty decent at first base" [9, p.5]. They also watch cartoons with Snoopy. There appear to be some students who are rather particular about music and who heard about or listened to music played by Def Leppard, Twisted Sisters, though it should be also admitted that with years Ella Fitzgerald is missing her popularity and becomes less known to Ukrainian students. Naturally, none of them have any idea and have never heard about James D.Welch, an American teacher and a musician. No wonder that my students have never heard or read about political and social icons of the USA whose writings were widely read and discussed in the 1980s. These icons just make a historical background of the context, reflect political and social issues which were important for American society and for R. J. Waller himself during a particular period of time, illustrate his personal likings, preferences, and in this way, contribute to the essay contextual decoding with a reference to temporal issues. The most crucial but yet positive change lies in the fact that modern non-native readers are quick in consulting Google if they really consider this information essential and relevant to them. This better and easier access to background knowledge makes context decoding of any foreign literary piece faster, easier, and more effective than ever before.

Conclusions. An essay cannot be considered less expressive or less figurative kind of literature than fiction. It may surpass even some fiction pieces as for its emotional and reflexive effects on the readers. It is quite logical and natural because their authors aim primarily at sharing and presenting publicly their personal views and ideas on political, social, cultural, educational and many other urgent and hot issues which their readers may be currently facing. Being predetermined to express personal views and ideas on the issues under consideration, R. J. Waller in his essay purposely and intentionally turns to a variety of tools to convey ironical senses in order to emphasize his messages. Ironical senses produced by Waller come along in both linear and vertical contexts. The former are realized by means of lexical and syntactical means, while the latter are expressed by basic textual categories and are viewed in terms of coherence, cohesion, retrospection, intertextuality, which, in their turn, are actualized through repetition, citation, parody. When analyzing Waller's piece as a whole, we evidently deal with associative irony context decoding. Ironic senses are not easy to recognize immediately, as they come gradually as the story progresses. They are added up to reveal distant relations between those parts of the text which are predetermined to produce ironical senses. Therefore, the author's irony is very effective for description of characters, their features and behavior, and, what is more, presentation of his personal views, ideas, and considerations. It is the structural complexity of associative irony applied by the author that allows to express a variety of emotions about facts, events, characters, both positive and negative. Presented explicitly and implicitly, Waller's modality expression is rich in shades and varieties. Some of modality relations with Waller's context are far from being simple and easy to see. Readers are able to synthesize them while reading, and background knowledge significantly enforces this ability. Background knowledge, being initially oriented to native readers, needs a wider view and deeper comprehension on the part of non-native readers. It also appears to be flexible and sensitive to temporal issues. The article can be of some practical use for those who study modern literature of the USA, are concerned about English literary discourse, contextual semantics, presupposition, subjective and evaluative modality, intercultural issues. 


\title{
ЗНАЧЕННЯ ІРОНІЇ ТА ФОНОВИХ ЗНАНЬ У ДЕКОДУВАННІ КОНТЕКСТУ ECE P. ДЖ. УОЛЛЕРА “EXCAVATING RACHEL'S ROOM”
}

\author{
А. М. Дядечко \\ Кандидат філол.наук, доцент \\ ORCID ID 0000-0002-4505-5094 \\ Сумський державний університет \\ вул.Р.-Корсакова, 2, м. Суми, 40007, Україна \\ dyadechko@hotmail.com
}

У статті розглянуто феномен іронії, яка є типовою рисою не тільки сучасних літературних творів, а й міжособистісної комунікації в цілому. Привернуто особливу увагу до засобів створення, реалізації та декодування іронії у сучасній американській нехудожній прозі, зокрема в одному з есе Роберта Джеймса Уоллера. Вказано на екстралінгвістичну природу іронії $i$ ï контекстуальну зумовленість. Визначено два типи іронії: ситуаџійну і асоціативну. Більш детально розглянуто асоціативний тип іронї, пов'язаний частіше за все з мега-контекстами. Описано практику ї̈ контекстуального декодування на основі використання базових категорій $i$ принципів контекстуальної семантики: когерентності, когезії, ретроспекиї, інтертекстуальності. Проілюстровано $i$ конкретизовано також складну багаторівневу структуру асочіативної іронії иляхом формального логічного, стилістичного, компонентного аналізу тексту есе і виявлення імпліцитно представлених значень і смислів. Наведені приклади повторів, ичитації та пародії.

Досліджено роль фонових знань у відновленні прямих смислів, які насправді має на увазі автор есе. Визначено та надано ту специфічну додаткову інформацію, яку потребують неангломовні читачі як для сприйняття інтениій, роздумів та емоиій Р. Дж. Уоллера, так $i$ для декодування створених ним іронічних смислів. Вказано також на мінливість часових характеристик фонових знань.

Ключові слова: іронія, ситуативна іронія, асоціативна іронія, контекстуальне декодування, суб'єктивно-оціночна модальність, фонові знання.

\section{REFERENCES}

1. Muecke, D. C. The Compass of Irony [Текст] / D. C. Muecke. - London : The University of London, 1969. - 264 c. 11

2. Galperin I.R. Stylistics. Retrieved from: https://vdocuments.site/irgalperinstylistics-3rd-1981-full.html

3. Pokhodnya S.I. Lingual means of expressing irony in English. Kuiv: Naukova Dumka, 1989. - 126p.

4. Halliday M.A.K., Hasan R. Language, context and text: aspects of language in social-semiotic perspective. Oxford: Oxford University Press, 1991. - 126p.

5. Brown G., Yule G. Discourse analysis. Cambridge: Cambridge University Press, 1996. - 288p.

6. Voloshchuk I.I. About contextual determination of irony. Retrieved from: http://www.irbis-nbuv.gov.ua/cgi-bin/irbis_nbuv/cgiirbis exe?I21DBN=LINK\&P21DBN=UJRN\&Z21ID $=\& S 21 \mathrm{REF}=10 \& \mathrm{~S} 21 \mathrm{CNR}=20 \& \mathrm{~S} 2$ $1 \mathrm{STN}=1 \& \mathrm{~S} 21 \mathrm{FMT}=\mathrm{ASP} \_$meta\&C21COM=S\&2_S21P03=FILA=\&2_S21STR=N zfn_2011_1_10

7. Katz Y., Fadieieva Y. Irony and means of its realization in English literary discourse. Retrieved from: http://tractatus.sumdu.edu.ua /Arhiv/2018-1/7.pdf

8. Zhuikova M.V.,Lytvyn O.L.Means of irony in the books by J.K.Jerome "Three men in a boat"and "Three men on the Bummel." Retrieved from: http://www.irbisnbuv.gov.ua/cgi-bin/irbis_nbuv/cgiirbis_

64.

exe? 
I21DBN=LINK $\&$ P21DBN=UJRN $\& Z 21 \mathrm{ID}=\& S 21 \mathrm{REF}=10 \& \mathrm{~S} 21 \mathrm{CNR}=20 \& \mathrm{~S} 21 \mathrm{ST}$ $\mathrm{N}=1 \& S 21 \mathrm{FMT}=A S P \_m e t a \& C 21 \mathrm{COM}=\mathrm{S} \& 2 \_S 21 \mathrm{P} 03=\mathrm{FILA}=\& 2 \_S 21 \mathrm{STR}=\mathrm{vdnu}$ g_2012_1-2_5

9. Waller R.J. Old Songs in a New Cafe. New York: Warner Books, Inc., 1994. $172 \mathrm{p}$.

10. Essay. Retrieved from:https://www.dictionary.com /browse/essay

11. Kam'yanetz A., Nekryach T. Intertextual irony and translation. Retrieved from:http://old.lingua.lnu.edu.ua/ukrainian/Kamyanets.pdf

12. Kharashchuk A. Irony and its specific translation in fiction.Retrieved from:http://englishcontext.kpnu.edu.ua /2019/04/08/ironiia-ta-spetsyfika-iiperekladu-u-khudozhnikh-tekstakh/

14. Shkitska I.Y. Ways and tools of ironic verbalization within a manipulative positive discourse. Retrieved from:http://oaji. net/articles/2017/918-1525256735.pdf

16. Kalyta O.I. Means of irony in short prose pieces. Retrieved from: http://enpuir.npu.edu.ua/handle/123456789/11395

17. Kalyta O. Ironic nominations of politicians in modern Ukrainian blogosphere. Retrieved from:https://scholar.google.com.ua

\section{СПИСОК ВИКОРИСТАНИХ ДЖЕРЕЛ}

1. Muecke, D. C. The Compass of Irony [Текст] / D. C. Muecke. — London : The University of London, 1969 . - 264 c. 11

2. Galperin I.R. Stylistics [Електронний pecypc].- Режим доступу: https://vdocuments.site/irgalperin-stylistics-3rd-1981-full.html

3. Походня С.И. Языковые средства выражения иронии в английском языке. Київ:Наукова думка, 1989. - 126с.

4. Halliday M.A.K., Hasan R. Language, context and text:aspects of language in social-semiotic perspective. Oxford:Oxford University Press, 1991. - 126p.

5. Brown G., Yule G. Discourse analysis. Cambrige: Cambridge University Press, 1996. - 288p.

6. Волощук I.I. Про контексту зумовленість іронії [Електронний ресурс].Режим доступу: http://www.irbis-nbuv.gov.ua/cgi-bin/irbis_nbuv/cgiirbis _64. exe?I21DBN=LINK\&P21DBN=UJRN\&Z21ID $=\& S 21 \mathrm{REF}=10 \& S 21 \mathrm{CNR}=20 \& \mathrm{~S} 2$ $1 \mathrm{STN}=1 \& \mathrm{~S} 21 \mathrm{FMT}=\mathrm{ASP} \_$meta\&C21COM=S\&2_S21P03=FILA=\&2_S21STR=N zfn_2011_1_10

7. Katz Y., Fadieieva Y. Irony and means of its realization in English literary discourse. [Електронний ресурс].- Режим доступу: http://tractatus.sumdu.edu.ua /Arhiv/2018-1/7.pdf

8. Жуйкова М.В., Литвин О.Л. Засоби іронії у творах Дж.Джерома “Three men in a boat" та "Three men on the Bummel." [Електронний ресурс].- Режим доступу: http://www.irbis-nbuv.gov.ua/cgi-bin/irbis_nbuv/cgiirbis_ 64. exe? I21DBN=LINK\&P21DBN=UJRN\&Z21ID $=\& S 21 \mathrm{REF}=10 \& S 21 \mathrm{CNR}=20 \&$ S21ST $\mathrm{N}=1 \& \mathrm{~S} 21 \mathrm{FMT}=\mathrm{ASP} \_$meta $\& \mathrm{C} 21 \mathrm{COM}=\mathrm{S} \& 2 \_\mathrm{S} 21 \mathrm{P} 03=\mathrm{FILA}=\& 2 \_\mathrm{S} 21 \mathrm{STR}=\mathrm{vdnu}$ g_2012_1-2_5

9. Waller R.J. Old Songs in a New Cafe. New York: Warner Books, Inc., 1994.172 p.

10. Essay. [Електронний pecypc].- Режим доступу:https://www.dictionary.com /browse/essay

11. Кам'янець А., Некряч Т. Інтертекстуальна іронія і переклад. [Електронний pecypc].- Режим доступу:http://old.lingua.lnu.edu.ua/ukrainian/Kamyanets.pdf

12. Харащук А. Іронія та специфіка іï перекладу у художніх текстах. [Електронний peсурс].- Режим доступу:http://englishcontext.kpnu.edu.ua /2019/04/08/ironiia-ta-spetsyfika-ii-perekladu-u-khudozhnikh-tekstakh/ 
14. Шкіцька І.Ю. Способи та засоби вербалізації іронії в маніпулятивному дискурсі позитиву. [Електронний ресурс].- Режим доступу:http://oaji. net/articles/2017/918-1525256735.pdf

16. Калита O.I. Засоби іронії в малій прозі. [Електронний ресурс].- Режим доступу: http://enpuir.npu.edu.ua/handle/123456789/11395

17. Kalyta O. Ironic nominations of politicians in modern Ukrainian blogosphere. [Електронний ресурс].- Режим доступу:https://scholar.google.com.ua

Received: 20 June, 2019 